Nig. J. Biotech. Vol. 35 (2018) 99-104 ISSN: 01891731

Available online at

http://www.ajol.info/index.php/njb/index and www.biotechsocietynigeria.org

DOI: https://dx.doi.org/10.4314/njb.v35i1.12

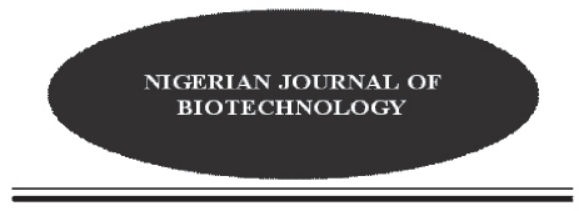

\title{
Assessment of genetic diversity in plantain (Musa paradisiaca L.) using RAPD marker
}

Brinemugha B. E. *, Emede T. O., Nwaoguala C. N. C. and Omere A. E. Department of Crop Science, Faculty of Agriculture, University of Benin, Nigeria

Copyright resides with the authors in terms of the Creative Commons License 4.0.
(See $\underline{\text { http://creativecommons.org/licenses/by/4.0/). }}$
$\begin{gathered}\text { Condition of use: The user may copy, distribute, transmit and adapt the work, but must recognize } \\ \text { the authors and the Nigerian Journal of Biotechnology. }\end{gathered}$

Abstract

Insufficient information on the diversity of plantain and its relationship with other Musa species in the Musa genus has been cited as one of the major problems hindering genetic improvement within the genus. Hence, this study aimed to assess genetic diversity among plantain cultivars using RAPD markers. Fifteen plantain cultivars were deployed for this study, comprising of ten landraces sourced from different parts of Edo state and five hybrids from International Institute of Tropical Agriculture (IITA), Ibadan. The study revealed a total number of 2 alleles across 4 RAPD primers analysed, effective number of alleles $\left(N_{e}\right)$ ranged from 1.14-2.0, Nei's genetic distance $(H)$ had a mean of 0.30. Polymorphic information content (PIC) ranged from 0.12 (OPT-07) to 0.23 (OPH$06), 0.40$ (OPT-01) and 0.46 (OPT-06), with a mean of 0.30 , which indicated that markers used were polymorphic. Dendrogram revealed 2 clusters; MP EKO and MP ACH both from Edo state displayed genetic relatedness and were more related to MP No. 2 from IITA than MP 07 FPT in the same cluster. The results suggest that though the hybrids have been improved for special qualities, the landraces from Edo state could possess some genes of interest in plantain breeding program.

Keywords: Musa paradisiaca, RAPD, genetic variability, markers

*Corresponding Author: emmanuel.brinemugha@gmail.com

\section{Introduction}

Plantains and Bananas belong to the Musaceae family. The cultivated varieties of Musa species are major staple fruit crop in developing countries (Swennen and Wilson, 1983). The large diversity that occurs in plantain, due to genetic variation formed through natural hybridization and somatic mutation, has resulted in a variety of cultivars. In Africa, one hundred and sixteen plantain cultivars have been identified and the number of plantain cultivars has been reported to vary from country to country (Swennen, 1990).

This Genetic variability in plants is important in distinguishing between species, subspecies and populations, and also for plant conservation and management (Sen et al.,
2010). Knowing and understanding the genetic make-up of crops represents a great opportunity not only to explain the functions of genes of interest, but also to detect regions in the genome that could present polymorphisms associated with agronomic traits (Liu, 1997).

The advent of modern DNA technologies and bioinformatics has aided sequencing and assembly of genomes of economically important crops (Feuillet et al., 2011). DNA marker techniques have been widely used in Musa genetics and in taxonomy, cultivar true to type assessment and genetic linkage map development. These approaches provide insight into the plant genome and produced important genetic data for breeders (Ortiz and Swennen, 2014). 
Randomly amplified polymorphic DNA (RAPD) is a method that is inexpensive, rapid and reliable for characterizing the crop genotype (Jain et al., 2007). The molecular markers have been used in Musa to elucidate the genome composition (Pillay et al., 2000). Agoreyo et al. (2008) reported genetic variability in plantain cultivars from Nigeria and Jamaica using arbitrarily primed PCR. They reported that the Nigerian cultivars were placed in a distinct group from the Jamaican cultivars.

Evaluation of genetic diversity and genetic structure in crops has important implications for plant breeding programs and the conservation of genetic resources. Genomic information sheds light on polymorphisms that can be used in plant breeding programs (Kumar, 2010). Plantain landraces have broad genetic base which have evolved to adapt to various environments. Therefore the study was carried out to determine the genetic diversity in plantain landraces.

\section{Materials and methods}

Plant materials

Fifteen genotypes of plantain (Musa, $A A B$ genome), which include 15 landraces collected from some major plantain producing districts in Edo State and 5 hybrids from the germplasm collection of the International Institute of Tropical Agriculture (IITA), Ibadan were used in the study (Table 1). Leaf samples were obtained from the genetic materials.

\section{DNA extraction}

Total genomic DNA was isolated from the leaves of the plantain genotypes, according to the modified mini-preparation proposed by Dellaporta et al. (1983). Approximately $200 \mathrm{mg}$ $(0.2 \mathrm{~g})$ each of the samples was used for DNA extraction. DNA quality and concentration were assayed using a Nanodrop Spectrophotometer ( Thermo scientific, ND 1000 Spectrophotometer).

Table 1: Accessions used in the study

\begin{tabular}{lll}
\hline Accession & Biological Status & Collection Site \\
\hline MP ACH & Landrace & Auchi \\
MP EKO & Landrace & Ekosodin \\
MP CGM EKO & Landrace & Ekosodin \\
MP EKP & Landrace & Ekpoma \\
MP AUC TWN & Landrace & Auchi \\
MP DB FPT & Landrace & UNIBEN \\
MP 07 FPT & Landrace & UNIBEN \\
MP 08 FPT & Landrace & UNIBEN \\
MP 09 FPT & Landrace & UNIBEN \\
MP 10 FPT & Landrace & UNIBEN \\
MP 5295-1 & Hybrid & IITA \\
MP 16952 & Hybrid & IITA \\
MP 1378 & Hybrid & IITA \\
MP No. 2 & Hybrid & IITA \\
MP 4698-1 & Hybrid & IITA \\
\hline
\end{tabular}

Table 2: The RAPD primers used for PCR amplification

\begin{tabular}{|c|c|}
\hline RAPD Primers & Base Sequence \\
\hline OPT -01 & 5 -GGGCCACTCA-3 \\
\hline OPT - 06 & 5 -CAAGGGCAGA- 3 \\
\hline OPT -07 & 5 -GGCAGGCTGT- 3 \\
\hline $\mathrm{OPH}-06$ & 5 -ACGCATCGCA- 3 \\
\hline
\end{tabular}




\section{RAPD-PCR analysis}

A total of ten (10) RAPD primers were optimized of which four, OPT-01, OPT-06, OPT07 and $\mathrm{OPH}-06$ with the most polymorphism were used for PCR amplification (Table 2).

\section{Data analysis}

RAPD bands were scored as present (1) or absent (0) and genetic analysis was based on the scoring. The following were estimated using the Population Genetic Analysis Software (POPGENE) version 1.31 (Yeh et al., 1999). Average number of alleles $\left(n_{a}\right)$, number of effective alleles $\left(n_{e}\right)$ (Kimura and Crow, 1964), Shannon's index (I) (Shannon and Weaver, 1949; Lewontin, 1972) and Nei's (1973) gene diversity were determined. Dendrogram was constructed based on Jaccard dissimilarity coefficient using the PAleontological Statistics (PAST) package (Hammer et al., 2001).

\section{Results and Discussion}

This study focused on the genetic variability inherent among plantain varieties studied. The genetic composition of a population is often delineated in terms of number of alleles, frequency of alleles and heterozygosity (Resmi et al., 2011). The average number of allele per locus was 2 (Table 3 ). All markers had the same allele number (2). The average number of observed alleles (2.0) across 4 RAPD loci and 15 accessions analysed in this study was low compared to an average of 4.8 reported by Kiran et al. (2015) who analysed 10 Musa species across 5 RAPD loci. Effective number of alleles $(\mathrm{Ne})$ varied from 1.14 (OPT-01 and OPH-06) to 2.0 (OPT-06), while OPT-07 had a value of 1.80 with a mean of 1.52 across the loci analysed (Table 3). Ne of 1.52 across accession analysed was comparable to that recorded by Kiran et al. (2015); however, the mean of 1.33 for $\mathrm{Ne}$ reported by Lamare and Rao (2015) across 26 RAPD, 11 DAMD and 21 ISSR was lower than the mean obtained in the present study.

RAPD polymorphisms are the result of either a change in the nucleotide base that alters the primer binding site, or an insertion or deletion within the region of amplification (Williams et al., 1990). The differences in polymorphism could also be as a result of the differences in the amount of genetic variation that exist among the different accessions analyzed. For gene diversity $(\mathrm{H})$, OPT-06 had the highest value (0.50), followed by OPT-07 (0.44) and OPT-01 (0.12), OPH-06 (0.12) with an overall mean of 0.30 (Table 3 ), this was lower than the mean of 0.43 recorded by Mukunthakumar et al. (2013) across 10 RAPD markers. The low gene diversity recorded in this study may be due to the number of accessions

Table 3: Summary of Genetic Variation Statistics

\begin{tabular}{llllll}
\hline Locus & Na & Ne & H & I & PIC \\
\hline OPT-01 & 2.0 & 1.14 & 0.12 & 0.25 & 0.40 \\
OPT-06 & 2.0 & 2.0 & 0.50 & 0.70 & 0.46 \\
OPT-07 & 2.0 & 1.80 & 0.44 & 0.64 & 0.12 \\
OPH-06 & 2.0 & 1.14 & 0.12 & 0.24 & 0.23 \\
Mean & 2.0 & 1.52 & 0.30 & 0.46 & 0.30 \\
\hline
\end{tabular}

$\mathrm{Na}$ - observed number of alleles; $\mathrm{Ne}$ - effective number of alleles; $\mathrm{H}$ - gene diversity; I - Shannon's Information index.

Shannon information index which is the degree of polymorphism was within the range of 0.24 (OPH-06) to 0.70 (OPT-06) and had a mean of 0.46 (Table 3). The index (I) mean of 0.46 recorded in this study was also comparable to Resmi et al. (2016) with a mean of 0.49 for 5 Musa genomic groups using 10 RAPD markers and a mean of 0.48 by Kiran et al. (2015) across 5 RAPD markers. PIC values of each marker, varied for markers studied, 0.40 (OPT-01), 0.46 (OPT$06), 0.12$ (OPT-07), 0.23 (OPH-06) and 0.30 as mean (Table 3). According to the classification by
Botstein et al. (1980), PIC > 0.5 gives high information, PIC $>0.25$ but $<0.5$ gives moderate information and PIC $<0.25$ gives slight information. Values of PIC of RAPD used in this study were moderate with a mean of 0.30 . Choudhary et al. (2014) reported a PIC mean of 0.85 across 16 RAPD primers, and this was higher than the PIC mean of this study. The PIC mean of 0.36 across 26 RAPD loci reported by Lamare and Rao (2015) was comparable to the PIC mean recorded in this study. According to this study, PIC being a measure of the 
polymorphism of the marker (Shete et al., 2000), was not a function of the number of markers used but the polymorphic strength of the marker.

Dendrogram constructed based on Jaccard dissimilarity coefficient discriminated the 15 plantain populations, which was separated into two distinct clusters (Figure 1). MP 8FPT grouped independently of the two clusters. Cluster 1 consisted of MP EKO (Ekosodin, Edo state) and MP ACH (Auchi, Edo state) more related to each other and related to MP No. 2 (IITA, Ibadan) than MP 7FPT (UNIBEN, Edo state) in the same cluster.

\section{Similarity}

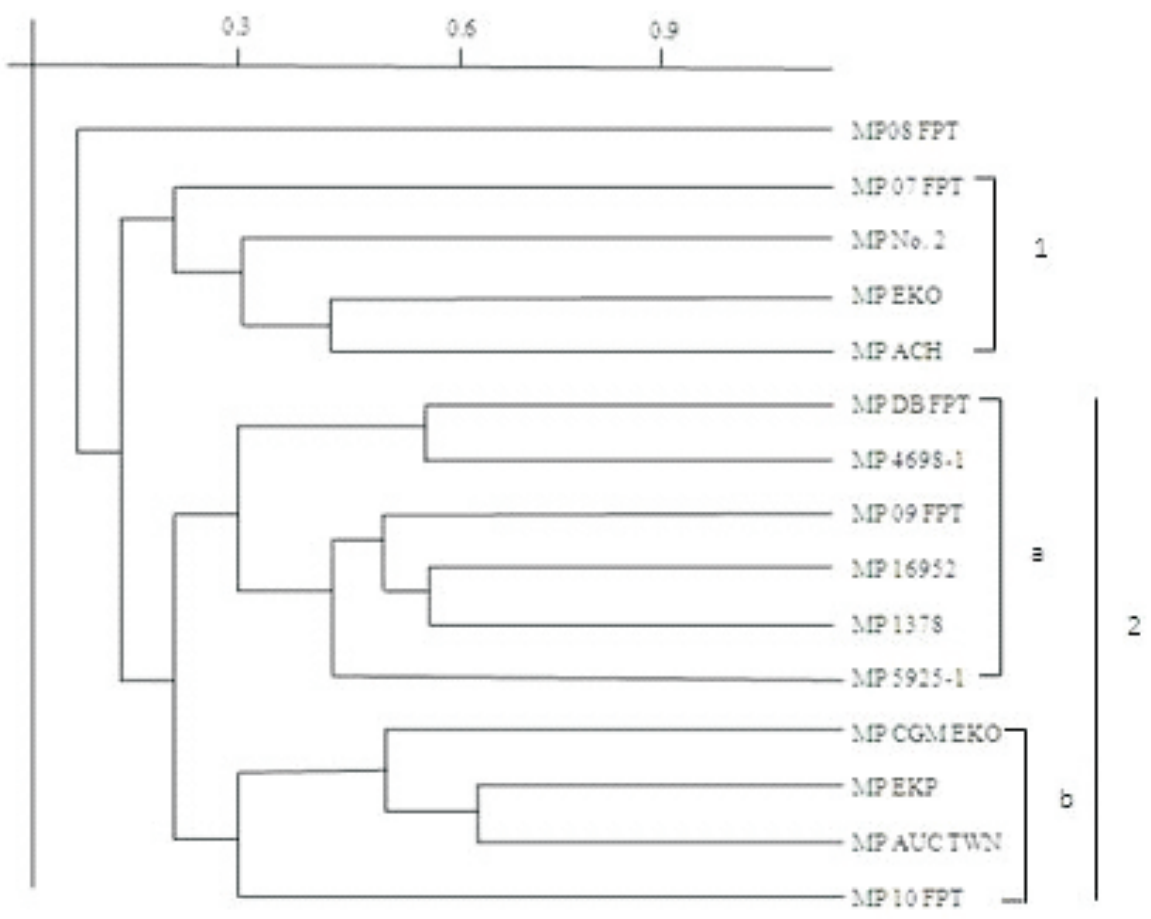

Figure 1: Dendrogram showing genetic similarity of plantain cultivars based on Jaccard dissimilarity coefficient

Cluster 2 consisted of two sub clusters, with sub cluster-a having MP DBFPT and MP 46981 more related than others, MP 16952 and MP 1378 were similar and more related to MP 9FPT, MP 59251 (IITA) grouped independently in this sub cluster. Sub cluster-b had MP 10FPT grouping independently, MP EKP was observed to be related to MP ACH TWN and more related to MP CGMEKO than MP 10FPT in the same sub cluster.

The cluster analysis as shown by the dendrogram indicated that the accessions from Edo state, Nigeria was grouped into the 2 clusters while four of the accessions from IITA grouped in cluster 2. MP EKO (Ekosodin, Edo state) and MP ACH from Auchi, Edo state grouped in cluster 1 suggesting more relatedness than MP No. 2 from IITA. Cluster 2 had two sub clusters, with sub cluster 1 having accessions from IITA (MP 16952 and MP 1378) more related than others in this group. MP EKP from Ekpoma and MP ACH TWN from Auchi both in Edo state grouped in the sub cluster b and were more related than other genotypes in the cluster as expected. Notwithstanding the results shown in the dendrogram, it is imperative to state that 4 RAPD loci might be insufficient in distinguishing populations sufficiently.?

In conclusion, RAPD markers were able to determine genetic variation among cultivars studied and is therefore useful in Musa characterization and cultivar identification for 
the improvement of Musa genetic resources. The results of the present study further shows that though hybrids have been bred for special qualities, some landraces could also possess some of the genes of interest needed in plantain breeding programs. Perhaps, Musa hybrids are more economically important than the Musa landraces, the landraces are the reservoirs for hybrid improvement, and research into existing gene pool of landraces using marker technology is recommended.

\section{References}

Agoreyo, B. O., Golden, K. D. and Brown, S. E. (2008). Analysis of genetic variability among plantain cultivars (Musa paradisiaca L.) using arbitrarily primed PCR techniques. Afr. J. Biotechnol. 7(8): 1041 - 1045.

Botstein, D., White, R. L., Skolnick, M. and Davis, R. W. (1980). Construction of a genetic linkage map in man using restriction fragment length polymorphisms. Am. J. Hum. Genet. 32: 314 331.

Choudhary, R., Keshavachandran, R., Menon, R., Khalekar, G., Singh, N. and Maruthiyottu, D. (2014). Molecular variability of plantain ecotypes from the genus Musa (Musaceae). Turk. J. Bot. 38: 827-834. https://doi.org/10.3906/bot-1312$\underline{61}$

Dellaporta, S. L., Wood, J. and Hicks, J. B. (1983). A plant DNA minipreparation: version II. Plant Mol. Biol. Rep. 1: 19-21. http://dx.doi.org/10.1007/BF02712670

Feuillet, C., Leach, J. E., Rogers, J., Schnable, P. S. and Eversole, K. (2011). Crop genome sequencing: lessons and rationales. Trends Plant S C i. $16(2): \quad 77-88$. https://doi.org/10.1016/j.tplants.2010.10.005

Hammer, O., Harper, D. A. T. and Ryan, P. D. (2001). Past: Paleontological Statistics software package for education and data analysis. Palaeon. Electronica 4(1): 1-9.

Jain, P. K., Saini, M. L., Pathak, H. and Gupta, V. K. (2007). Analysis of genetic variation in different banana (Musa specie and cultivars) based on D2 analysis and RAPD markers. Infomusa 10: 29-34. https://doi.org/10.5897/ajb2007.000-2304

Kimura, M. and Crow, J. F. (1964). The number of alleles that can be maintained in a finite population. Genetics 49: 725-38.

Kiran, U., Moahnty, S. K., Roy, P. S., Behera, L. and Chand, P. K. (2015). Genetic diversity among Musa cultivars from Odisha using RAPD markers. Sci. Res. Rep. 5(2): 118-124.

Kumar, D., Viborg, J., Nilsson, A. K. and Chabes, A. (2010). Highly mutagenic and severely imbalanced dNTP pools can escape detection by the S-phase checkpoint. Nuc. Acid Res. 38(12): $\begin{array}{lllllllll}3 & 9 & 7 & 5 & - & 3 & 9 & 8 & 3\end{array}$. https://doi.org/10.1093/nar/gkq128

Lamare, A. and Rao, S. R. (2015). Efficiency of RAPD, ISSR and DAMD markers in assessment of genetic variability and population structure of wild Musa acuminate Colla. Physiol. Mol. Biol. Plants 21(3): 349 - 358.

Lewontin, R. C. (1972). Testing the theory of natural selection. Nature 236 (5343): 181-182. https://doi.org/10.1038/236181a0

Liu, B.H. (1997). Statistical genomics: linkage, mapping and QTL analysis. CRC Press, p. 611.

Mukunthakumar, S., Padmesh, P., Vineesh, P. S., Skaria, R., Kumar, K. H. and Krishman, P. N. (2013). Genetic diversity and differentiation analysis among wild antecedents of banana (Musa accuminata Colla) using RAPD markers. Indian J. Biotechnol. 12: 493 - 498.

Nei, M. (1973). Analysis of gene diversity in subdivided populations. Proceedings of National Academic Sciences, USA 70 (12): 3321-3323. https://doi.org/10.1073/pnas.70.12.3321

Ortiz, R. and Swennen, R. (2014). From cross breeding to biotechnology - facilitated improvement of banana and plantain. Biotechnol. Adv. 32(1): 158-169. https://doi.org/10.1016/j.biotechadv.2013.09.0 $\underline{10}$ 
Pillay, M., Nwakanma, D. C. and Tenkuano, A. (2000). Identification of RAPD markers linked to $A$ and $B$ genome sequences in Musa. Genome 43(5): 763-767. https://doi.org/10.1139/gen43-5-763

Resmi, L., Kumari, R., Bhat, K. V. and Nair, A. S. (2011). Molecular characterization of genetic diversity and structure in South Indian Musa cultivars. Int. J. Bot. 7(4): 274-282. http://dx.doi.org/10.3923/ijb.2011.274.282

Resmi, L., Nair, A. R. and Nair, A. S. (2016). Population genetic structure and diversity analysis of South Indian banana cultivars. J. Plant Breed. Crop Sci. 8(1): 1-12. http://doi.org/10.5897/jpbcs2015.0519

Sen, S., Skaria, R. and Abdul Muneer, P. M. (2010). Genetic diversity analysis in Piper species (Piperaceae) using RAPD markers. Mol. B i o t e ch nol. 46 : $72-79$. https://doi.org/10.1007/s12033-010-9281-6

Shannon, C. E. and Weaver, W. (1949). The mathematical theory of communication. University of Illinois Press, Urbana, $117 \mathrm{pp}$.

Shete, S., Tiwari, H. and Elston, R. C. (2000). On estimating the heterozygosity and polymorphism information content value. Theor. Pop. Biol. 57: $\begin{array}{lllllll}2 & 6 & 5 & - & 2 & 7 & 1\end{array}$. https://doi.org/10.1006/tpbi.2000.1452

Swennen, R. (1990). Plantain cultivation under West African conditions. A reference manual of International Institute of Tropical Agriculture (IITA), Ibadan, Nigeria, 1-24.

Swennen, R. and Wilson, G. F. (1983). Response of plantain to mulch and fertilizer. International Institute of Tropical Agriculture, IITA, Ibadan, Nigeria. Annual Report, p. 187.

Williams, J. G. K., Kubelik, A. R., Livak, K. J., Rafalsky, J. A. and Tingey, S. V. (1990). DNA polymorphism amplified by arbitrary primer is useful as genetic marker. Nucleic Acids Res. 18: $\begin{array}{lllllllll}6 & 5 & 3 & 1 & - & 6 & 5 & 3 & 5\end{array}$. https://doi.oorg/10.1093/nar/18.22.653

Yeh, F. C., Yang, R. C. and Boyle, T. (1999). Popgene Microsoft Windows-based freeware for population genetic analysis release 1.31. University of Alberta, Alberta, Canada. 